\title{
Social Marketing for Digital Transformation: Digitalizing Social Action for the Development of Women at Risk of Exclusion
}

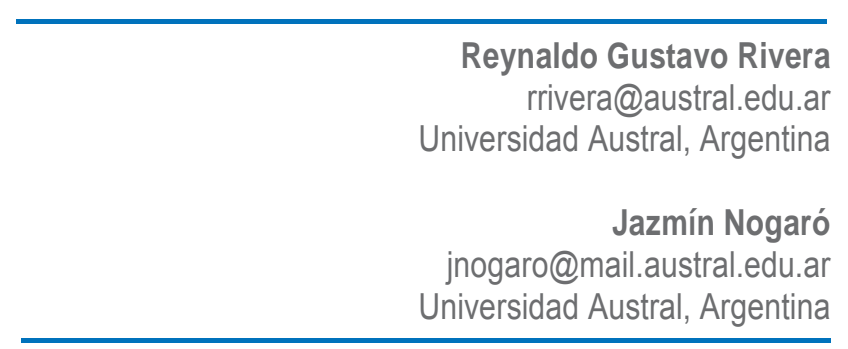

\begin{abstract}
The third sector, key to social and personal development, needs to evolve and adapt to the technological revolution and digitalization that accelerated due to the global pandemic of COVID-19.
\end{abstract}

Social marketing offers strategies and tools that allow digitalizing processes of female empowerment in contexts of poverty, violence, inequality, and social exclusion.

People living in these contexts were the ones that suffered the most from the pandemic, both due to the number of deaths coupled with a lack of access to quality health care, and an increase in interpersonal conflict. The latter aggravated by the mandatory isolation measures imposed by the governments, which made it practically impossible for civil society organizations (CSOs) to intervene.

This article presents a case of social marketing oriented to the development, implementation, and evaluation of a people-centered protocol (EduQualitas SM) for the digitalization of empowerment and positive personal development, based on interpersonal relationships and reflexiveness.

Through qualitative and quantitative methodologies, the study analyses the impact of its application in a social marketing campaign (Orientación Familiar Digital - OFD) that aimed to improve the quality of life of women in the area of greatest social exclusion in Argentina.

The implemented campaign sought to digitalize the formative processes of an international CSO and develop empathy, a fundamental capacity for the quality of life and the reduction of both structural poverty and violence against women. 
The impact assessment of EduQualitas SM was of a mixed design that included a quasiexperimental intervention without a control group, based on the Argentine adaptation of the Interpersonal Reactivity Index (IRI).

This research presents one of the first Latin American cases of CSO digitalization strategies for the development of empathy of women in situations of social exclusion.

\section{Resumen}

El tercer sector, clave para el desarrollo social y personal, necesita evolucionar y adaptarse a la revolución tecnológica y la digitalización que se aceleraron a partir de la pandemia global del COVID-19.

El marketing social ofrece estrategias y herramientas que permiten digitalizar procesos de empoderamiento femenino en contextos de pobreza, violencia, desigualdad y exclusión social.

Las personas viven en esos contextos fueron los que más sufrieron la pandemia, tanto por el número de muertes como de falta de acceso a un sistema sanitario de calidad y aumento de la conflictividad interpersonal. Esto último se agravó por las medidas de aislamiento obligatorio impuestas por los gobiernos, que imposibilitaron a las organizaciones de la sociedad civil (OSC) la intervención en el territorio.

El artículo presenta un caso de marketing social orientado al desarrollo, implementación y evaluación de un protocolo centrado en las personas (EduQualitas SM) para la digitalización del empoderamiento y el desarrollo personal positivo, basado en relaciones interpersonales y reflexividad.

A través de metodologías cualitativas y cuantitativas se analiza el impacto de su aplicación en una campaña de marketing social (Orientación Familiar Digital - OFD) que buscó mejorar la calidad de vida de mujeres de la zona de mayor exclusión social de la Argentina.

La campaña implementada buscaba digitalizar los procesos formativos de una OSC internacional y desarrollar la empatía, capacidad fundamental para la calidad de vida, la reducción de la pobreza estructural y la violencia contra las mujeres.

La evaluación de impacto del EduQualitas SM se realizó a través de un diseño mixto que incluyó una intervención cuasi-experimental sin grupo de control que utilizó la adaptación Argentina del Interpersonal Reactivity Index (IRI).

La investigación presenta uno de los primeros casos latinoamericanos de estrategias de digitalización de OSC para el desarrollo de la empatía de mujeres en situaciones de exclusión social.

Keywords: Social marketing, micro-learning, digitalization, empathy, women, social exclusion, interpersonal relations. 
Gustavo-Rivera, R. and Nogaró, J. (2020) Application of a Dialogic Social Marketing Model Based on Microlearning for the Development of Empathy Among Women at Risk of Exclusion, Vol.12(2): 52-69

\section{Introduction: pandemic and digital gap}

The Buenos Aires conurbation includes, from a political and socio-cultural point of view, the first and second "rings" (corona) of the Buenos Aires Metropolitan area, surrounding the city of Buenos Aires (Kessler, 2015, pp. 73-74).

According to the 2010 census, the area had a population of 9,916,715 people ( 25 percent of the country's total), of whom $34.1 \%$ are classified as poor. In addition, $49.6 \%$ of the children and teenagers in the conurbation live below the poverty line. In the country (Observatorio de la Deuda Social UCA, 2020b), the incidence of poverty reached, in September $2020,44.7 \%$, and indigence reached $10.3 \%$, while in the city of Buenos Aires, around which the conurbation grows, poverty does not exceed $9.2 \%$ of the population. The unequal distribution of resources is evident and is associated with the greater frequency of violence and the heightened impact of health emergencies such as COVID19.

Analysis of different reports on the issue (Observatorio de la Deuda Social UCA, 2020a) can verify that the conurbation is the Argentinian region that suffered the most due to the mandatory isolation policies and deaths caused by the virus. In addition to the health crisis, there is a raft of socioeconomic problems: disappearance of informal economic activities, household overcrowding and lack of basic utilities, and disruption of public preventive and healthcare services. According to Observatorio del Conurbano (OC UNGS, 2020), ever since the quarantine began in March 2020, more than a third of the conurbation's inhabitants have experienced difficulties accessing food and an increase in problematic consumption. The area had already been witnessing an increase in crime and gender-based violence, but since that month the number of reported cases of the latter have risen by at least 39\%. According to data from the Buenos Aires Province Public Prosecutor's Office, there were 27 femicides recorded in the province during the first half of 2020 (out of 160 in the country), a little over $50 \%$ of the 2019 total.

In this context, the CSOs deployed different strategies to continue collaborating with cohesion and social development in a context of mandatory isolation and global structural crisis, which negatively impacted their human and financial resources (see collective map of initiatives at http://territoriosenaccion.org/). The Government of the City of Buenos Aires' program "Mayores Cuidados" incorporated, in its first month of launch, 40,000 registered as volunteers. The program "UBA in Action", of the Faculty of Medicine, incorporated 7,000 (five times greater than previous years) and "Helpers" (CSO for assistance in emergency situations) exceeded 4,000.

To finance their operations, the CSOs gradually incorporated some crowdfunding practices. However, this type of initiative came in many cases from groups of citizens who did not have a stable relationship with the third sector. Such is the case, for example, of "Peña Solidaria Virtual", an organization created by people linked to the Argentinian folklore who, mobilized by the crisis generated by the pandemic, created a YouTube channel that reached within 5 months 3,960 subscribers that participated in live shows with artists, and raised donations of over USD 2,000 a week for different CSOs through a fintech service such as Mercado Pago. 
However, despite the increase in the number of volunteers and direct actions that could generate funds to alleviate the situations of poverty and exclusion, most CSOs were caught by surprise by the mandatory isolation restrictions without a digitalization strategy for their services, thus confirming the existence of digital gap in the third sector.

We consider digital gap the difference in internet access, data management skills and capabilities for digitalizing processes and activities between people and organizations.

Several studies carried out in developed countries suggest that, despite the growing professionalization of the CSOs, less than $58 \%$ of the organizations have expert personnel in digital technology, most of them do not develop a management culture adapted to the new paradigms, consider networks as a control factor over its operations and continue to focus its communications on mass advertising strategies (Hall et al., 2020). UNESCO highlighted the need to face the challenges of the digital revolution in the third sector as a necessary condition for the achievement of the $17^{\text {th }}$ objective of sustainable development (2016). According to the latest NGO Technology Report, over $80 \%$ of the CSOs use social medial, in developing countries over $40 \%$ use WhatsApp for communication with donors and volunteers, but, even in Europe, less than $45 \%$ use Customer Relationship Management (CRM) software. In Latin America, this indicator drops down to $22 \%$. In that region, less than $14 \%$ of the CSOs have an online store. In Spain, the NGO's Platform for Social Action (2019) shows that, despite the fact that $87 \%$ of CSOs have a Facebook profile, only $31 \%$ have online training services and capacities. Likewise, only $15.5 \%$ have a management system and only $19.8 \%$ have a marketing plan. All of this indicates that there is a digital gap in the third sector, especially in small CSOs (less than 10 employees): they do not use the full potential of digital communications, nor do they develop digital products and services, which would allow them to adapt to the fourth industrial revolution and overcome situations such as the ones generated by pandemics (Banco Interamericano de Desarrollo, 2017). Therefore, it is crucial to define what digital transformation is, identify the means for its implementation in the third sector and evaluate its effectiveness in social action programs aimed at the development of socially excluded people.

\section{Digital transformation of CSOs for development and quality of life}

The digital transformation of organizations refers to the models, strategies, and tactics which, based on technological tools and data science methodologies, generate economic, social, environmental, and cultural effects that transform the activities and sectors in which they are applied.

The phenomena of globalization, social acceleration (Rosa, 2013) and the development of technologies such as smartphones, internet of things, big data analysis, artificial intelligence (OECD, 2019) support digital transformation. The intensive use of data and the interconnection of complex socio-economic systems in platforms and ecosystems generate new forms of value creation that are disconnected from space and time, since products and services can be completely virtual and usable independent of the moment of their production. Such is the case of online training programs and business opportunities through mobile phones: "One area in which the digital transformation can 
support inclusive growth is the empowerment of women in developing countries... digital technologies can make an important contribution to their participation in the formal labor market and all the benefits that comes with the effort." (OECD, 2019, p. 74).

Digitalization implies changing: the way of connecting and creating value for users, the analysis and relationships with the competition and the context, the way of thinking and using data, the innovation processes that can be open, participatory, and iterative (Rogers, 2016).

In the case of CSOs, transformation implies rethinking the vision; automate processes that facilitate interactions with donors, volunteers, and beneficiaries; build and offer their services through platforms; design and innovate quickly and openly based on interactions with their target audiences; train people for change and continuous improvement.

Even though digitalization implies the intensive use of information and communication technologies, this aspect is only part of the transformation process. A key element is the substantial modification of how tacit and explicit knowledge is generated, used, and improved in organizations, which emerges in teams, in direct continuous contact with users/beneficiaries and stakeholders, taking advantage of the potential of distributed intelligence and developing programs which are constantly evaluated. Such is the case, for example, of character education programs based on evidence and big data (Rivera, 2019b).

The digitalization of social action programs allows improving the effectiveness of governments and CSOs in increasing the quality of life (Dutta \& Bilbao-Osorio, 2012). From this perspective, one of the critical areas for the prevention and reduction of violence is emotional development. The latter can be achieved through social marketing programs that influence "...communication styles, participation or recognition of one's own skills and values, social norms conforming to positive development and emotion management (mainly the empathic disposition)" (Rivera, Castro Sanchez, et al., 2019, p. 14), which is vital for the individual and collective quality of life (Segal, 2018).

In the Argentine context, the population of the Buenos Aires conurbation registers a high level of conflict in interpersonal relationships: most of the children receive inadequate or average psycho-social care that affects their socialization (Rodrigo et al., 2006). A recent study found that psychological distress is higher among the marginal working class: "Across the different urban regions, an increase in psychological distress is observed in the Buenos Aires conurbation in 2018, reaching the highest value of the series (24.4\%)" (Rodríguez Espínola \& Salvia, 2019). Precariousness influences the negative coping of stress, manifesting a negative or avoidant form of coping (Rodríguez Espínola \& Salvia, 2019).

From the multidimensional perspective of quality of life (Tonon, 2016), the improvement of interpersonal relationships skills increases well-being and life satisfaction. Empathy, compassion, caring, and understanding are aspects that positively contribute to the quality of life (Tono, 2017, pp.17, 21). 
Among these aspects, cognitive and affective empathy reduces the levels of conflict and violence, particularly domestic violence (Jolliffe \& Farrington, 2004) since it facilitates compassion and the development of schemes, attitudes and behaviors that favor positive moral action (Deane-Drummond, 2017). Empathy can be defined as a communicative action that generates emotional responses that come from the capacity to understand the other person and to put oneself in their place, which facilitates sharing their emotional state (Richaud, 2008).

The development of empathy is paramount to reducing structural poverty (Lane, 2001; Segal, 2007) and violence against women, which negatively affect the development of positive emotions (DeWall \& Baumeister, 2006). Empathy plays an essential role in the quality of intrafamily relationships. (Marcus \& Swett, 2003), the development of prosocial behaviors (Sze et al., 2012), job growth (Baron, 2013), decision-making (Jensen et al., 2017) and leadership (Choi, 2006).

Consequently, a social marketing strategy based on the digitalization of the development of skills and aimed towards improving interpersonal relations through the development of empathy, could increase, simultaneously, the efficiency of the CSOs and the quality of life of women experiencing social exclusion, as the example of the Buenos Aires conurbation shows.

\section{Social marketing for the digitalization of social action: implementation of a protocol for the development of empathy}

\section{Objectives and methodology}

The increase in violence against women in Argentina, especially in the Buenos Aires conurbation, prompted the authors of this research to design a social marketing strategy for the digitalization of family orientations programs designed for developing empathy.

Considering the theoretical framework described and previous research (Rivera, Castro Sanchez, et al., 2019), the marketing strategy would focus on the design and validation of a protocol that aims to increase empathy and the quality of life of women at risk of exclusion. This would make it possible to identify predictive factors of impact, guide public policies, and strengthen the stability and positive development of families. The present research's objective is to analyze the characteristics and impact of the social marketing strategy implemented and evaluated by two CSOs and an Argentine university in two cities of the Buenos Aires conurbation during the first phase of the mandatory isolation due to the COVID-19 pandemic.

The hypotheses of the study are:

$\mathrm{H} 1$ : Analyze the empowerment of beneficiary women produced by activities carried out exclusively by virtual means through a social network.

$\mathrm{H} 2$ : Evaluate the impact of the social marketing strategy and the implemented protocol on the empathy of the beneficiaries. 
H3: Analyze the results of a digitalization process of programs of a CSO with experience in training and empowering women.

This research uses a mixed design that included action-research based on a digital micro-learning strategy, semi-structured online interviews, and a quasi-experimental intervention without a control group. For the collection of data form the interviews, the QuestionPro platform was used. SPSS19 and NVivo12 were used for the analysis of quantitative and qualitative data.

\section{The EduQualitas SM social marketing protocol}

The use of scientifically validated protocols is common in disciplines such as epidemiology (see, for example, (Bartholomew et al., 2016; Hockenhull et al., 2012)), which employ them for the development of effective behavioral-change and riskprevention interventions. Describing the stages of a process and assessing its effectiveness contributes to improving and replicating it in the future. However, there are few examples of protocols developed for social marketing or for improving the quality of life of individuals at risk of exclusion (R. G. Rivera, Castro Sanchez, et al., 2019).

To define the social marketing strategy, the research team designed, based on results of previous projects (R. Rivera, 2011, 2013, 2019a, 2019b; R. Rivera et al., 2016; R. G. Rivera, Arrese, et al., 2019) and the Intervention Mapping protocol (Bartholomew et al., 2016).

The EduQualitas SM protocol has six stages:

1. Analysis of the problematic situation:

a. Definition and analysis of target population.

b. Analysis of context, capacity, experiences, and implemented projects.

c. Definition of value/issue to resolve.

d. Identification of intervention opportunities.

2. Project team:

a. Organization of the team.

b. Reflection sessions and schedule.

c. Identification of stakeholders, platforms, and work processes.

d. Definition of concepts and methods to be used.

e. Formulation of hypotheses and scenarios.

f. Definition of the theoretical model to be implemented.

3. Model of change matrix.

a. Logic framework (specific objectives, expected results, activities, followup indicators).

b. Selection and strategic analysis of main stakeholder (CSO), as well as its context and beneficiaries.

c. Selection of phases of change for beneficiaries.

d. Definition of value proposition and type of product to be designed and used.

4. Design of the program.

a. Analysis and systematization of available resources. 
b. Search for resources, definition of sequence (roadmap), and elaboration of primary components (including the implementation protocols).

c. Definition of marketing mix.

d. Selection of implementation messages, techniques, and platform(s).

5. Implementation.

a. Personalization of components and platform for the CSO.

b. Training of trainers. Generation of competencies.

c. Ex-ante measurement.

d. Promotion, execution, and monitoring of implementation.

e. Resolution of problems.

f. Ex post measurement.

6. Assessment.

a. Analysis of qualitative and quantitative data.

b. Analysis of causal factors.

c. Project report.

d. Presentation of report and provision of final training to the CSO.

e. Analysis of possible program improvements.

\section{Social Marketing Strategy for digitalization: The use of micro-learning}

The EduQualitas SM protocol allowed the analysis of the situation of women in the Buenos Aires conurbation and the confirmation of the importance of empathy as a key capacity for de development of gender equality, violence prevention and social inclusion.

Once the team and the theoretical model to be implemented were defined, the CSO ANSPAC, an organization founded in 1974 in Mexico with headquarters in 14 countries of America and Span, was selected among different alternatives. Said CSO was selected not only for its experience in the territory but also because their main objective is to respond to family disintegration, caused by the crisis of values in families, through the training and comprehensive improvement of women, with the objective of contributing to the development of society. It has more than 112,000 members who are distributed by territories composed of coordinators who teach face-to-face courses designed to improve women's human, moral and technical skills.

Its program addresses topics such as self-knowledge, emotion management and interpersonal relationships. The mandatory isolation imposed by the Argentine Government on March 18 of 2020 forced ANSPAC volunteers to respect social distancing and avoid all contact with their beneficiaries in a context and circumstances that made it especially necessary due to the increase in loneliness and hardships of women. Until till that point, the CSO had not developed a strategy to digitalize its training services and support processes.

Considering the experience of the Italian CSO, the training program of Digital Family Orientation (OFD) was developed based on the micro-learning methodology, a perspective aimed towards the design and management of fragmented and continuous didactic content, of short duration, that can be used at any time and place, can be quickly consumed and shared, and generates concrete results in the short term (Salinas \& 
Marín, 2015). Micro-learning eases the development of skills through a modular, stepby-step process, through small pieces that form a deeper and broader connected knowledge in the long term (Trabaldo et al., 2017).

Table 1 presents the EduQualitas SM protocol applied to the ANSPAC case and the marketing mix.

Table 1. EduQualitas SM protocol and marketing mix. Source: compiled by authors

\begin{tabular}{|c|c|}
\hline Analysis & $\begin{array}{l}\text { Identification of the need to increase empathy and accompany the } \\
\text { beneficiary women during a period of preventive isolation. }\end{array}$ \\
\hline Team & $\begin{array}{l}\text { The Austral University and InterMedia Social Innovation define the } \\
\text { team, which establishes agile methodologies for the project and } \\
\text { designs the theoretical implementation model. }\end{array}$ \\
\hline $\begin{array}{l}\text { Matrix and } \\
\text { product } \\
\text { definition }\end{array}$ & $\begin{array}{l}\text { Selection of the CSO. Meetings with the CSO coordinators. } \\
\text { Analysis of the problem and past experiences. Shared definition of } \\
\text { the main characteristics of the product: } \\
\text { a) Micro-learning program } \\
\text { b) Created content based on scientifically validated materials } \\
\text { (McLaren, 2013; Richaud, 2008). } \\
\text { c) Definition of the development stages: Training in family } \\
\text { relationships, emotion management, empathy as an emotion and } \\
\text { empathic disposition } \\
\text { d) Monitoring and evaluation of budget changes }\end{array}$ \\
\hline $\begin{array}{l}\text { Design and } \\
\text { definition of } \\
\text { price, place, } \\
\text { and promotion }\end{array}$ & $\begin{array}{l}\text { The project team prepared implementation guides and trained the } \\
\text { ANSPAC coordinators. The program would be provided free of } \\
\text { charge, with the women's commitment to complete it to receive } \\
\text { certification from the University. } \\
\text { The free WhatsApp platform would be used due to the } \\
\text { characteristics of confidentiality and direct and immediate contact } \\
\text { between the coordinators and the beneficiaries. The promotion } \\
\text { would only reach women participating in ANSPAC programs. }\end{array}$ \\
\hline Implementation & $\begin{array}{l}\text { It was held between May } 13^{\text {th }} \text { and June } 8^{\text {th }} \text { in two cities in the Buenos } \\
\text { Aires conurbation. The project team used the following platforms: } \\
\text { MS Teams, Zoom, WhatsApp and Google Drive. }\end{array}$ \\
\hline Assessment & $\begin{array}{l}\text { The baseline was determined using an online survey that the } \\
\text { beneficiaries completed through the QuestionPro platform. In } \\
\text { addition to weekly monitoring by the coordinators, a post-test } \\
\text { assessment survey was carried out in the first week of June, through } \\
\text { the same platform and using the essential variables for the impact } \\
\text { analysis. }\end{array}$ \\
\hline
\end{tabular}

The program or product was developed using the theory of change based on persuasion (Prochaska \& DiClemente, 1982). For this reason, the first module is for the transition from the stage of pre-contemplation to contemplation, sensitizing women about the importance of empathy. In the second module, the beneficiaries are motivated to grow in emotional intelligence. This way, they can transform the theoretical consideration into a practical plan of action. The third module eases the learning and improvement of emotional and cognitive empathy, which makes it easier to put the proposed change in motion. In the fourth module, women are helped to plan and implement change in concrete actions. Interventions imply greater commitment and development as each module progresses. 
The designed program was completely digital and reusable by ANSPAC and other CSOs. It lasted four weeks or modules, each involving four interventions, to which participants were expected to devote one hour per week. Each intervention consisted of micro-messages with texts, videos, images, and activities. The messages were prepared by the project team in conjunction with ANSPAC coordinators, who maintained direct contact with the women, sent the messages, in a personalized way, through WhatsApp. The personalization of microlearning facilitates acceptance and increases the level of commitment. The responses of the participants were consolidated by the coordinators and sent to the project leaders as material for impact assessment.

Following the theoretical model, the first intervention only required the consumption of content, while in the final intervention each participant carried out an assignment, which involved, for example, completing a survey, writing, sketching, or looking for cases of empathetic disposition in their social media.

Module 1 explored family relations, so that participants could map their current family situation. Module 2 dealt with emotion management in order to achieve the development of emotional intelligence; participants were encouraged to think about their own emotionality and, in turn, communicate it. Finally, and most importantly, the module fostered recognition of the emotionality of others in order to start thinking about empathy. Module 3 approached empathy as an emotion, in terms of recognizing it and developing emotional and cognitive empathy for application in everyday life. In turn, Module 4 focused on the development of empathic disposition in a practical manner, applying the theory learned to everyday online (on the participants' social media accounts) and offline (in their interpersonal relations with family members) situations.

Socioeconomic status was a decisive factor in the selection of the communication channel used by the social marketing program. Most of the participants did not possess the technology and connectivity required to access a website from which they could download the materials. For this reason, a platform (WhatsApp) and user-friendly language were used to encourage them to complete the course, in an accessible format that did not require specific technological abilities nor the consumptions of available data on a mobile device.

The program was offered free of charge to beneficiaries and ANSPAC, who would explore a digitalization strategy and improve the digital skills of their coordinators from geographical zone chosen.

The promotion was carried out through ANSPAC's internal channels and two virtual presentation sessions.

The target population selected for the implementation were ANSPAC beneficiaries who live in the areas most affected by the pandemic if the Buenos Aires conurbation. In addition to the CSO, the main stakeholders in the campaign were the ecosystem of social entrepreneurs and local governments from the conurbation. 


\section{Results of the Digital Family Orientation (DFO) campaign}

The implemented strategy achieved empowering the beneficiary women $(\mathrm{H} 1)$ through a completely virtual program that had high adherence from the coordinators and participants in the two zones where it was implemented (San Miguel and Bancalari). Although the women live in the same geographical area, the coordinators and participants pertain to different socioeconomic levels: the coordinators are upper-middle and middle class, while the beneficiaries are of low socioeconomic status. This socioeconomic distinction is part of ANSPAC's methodology and is aimed towards increasing social cohesion and equality.

The program accomplished some of the stated objectives: it increased participants' empathic practices and social participation capabilities. The beneficiaries acknowledged an increase in their self-control during difficult situations, as well as a greater level of interest in and compassion for the suffering and unfair treatment of others, especially children; participants learned the importance of treating them with respect and giving them a space for dialogue in the home. In the words of one of the participants the program taught her: "To be more tolerant and see each situation from different points and listen to make better decisions."

Table 2 summarizes the main results across the dimensions of empathy on which the campaign sought to make an impact.

Table 2. Qualitative impact analysis. Source: compiled by authors.

\begin{tabular}{ll}
\hline $\begin{array}{l}\text { Dimension } \\
\text { and module }\end{array}$ & Beneficiaries response to the contents of the program \\
\hline Empathic & Identify situations of empathy: \\
concern & "Having to share something with a person who you don't like but you \\
Modules 1 & put on a brave face and treat them with respect." \\
and 3 & "Depending on the phrase I write, when I post a positive message, I \\
& feel very good ... excited about what'll be said to me. For me it's super \\
& important .... I'm always attentive to the needs of people, especially \\
& family. I try to be there and contribute however I can...." \\
& "I'm not really one to say whether something's right or wrong ...." \\
& "Only on occasions when it comes up" \\
& "But it'd be nice to try to say it every day" \\
& "Cmpathy with children: \\
& my children with violence or bad habits my children will grow up in the \\
& same way, that's what I think." \\
& "I am a self-critic ....I was raised under a rod, as they say ... and in \\
& truth I don't do what was done to me. There are people who tell me \\
I'm doing the wrong thing by sweet-talking the kids, that they'll never \\
do as they're told and I have to smack them now and again so they \\
grow up strong ... \\
And I tell them it's not my way"
\end{tabular}


speak from the heart and not from anger because if words are abused they are weapons that leave terrible marks."

"Sometimes it's a little easier to understand the position of another even if they apparently hurt us without cause, and sometimes it hurts so much that it makes it difficult. It's also difficult to understand the reason at times."

"I don't argue with my family, thank God. I argued with a neighbor a few months ago. I found it tough because I didn't expect her to attack me in that way. And she might have found it tough not because she spoke badly to me but because she didn't expect me to react like that." "I learned that you always have to dialogue with civilized people, to solve any problem."

Fantasy Reaction to conflicts:

Modules 1, 2 "I try to avoid fighting in front of the children. If it happens, I explain to and 4 them that they're differences between adults and it's nothing serious, that they shouldn't be sad because everything's alright and it has nothing to do with them. I apologize for what happened"

Negative emotions:

"A negative situation that was passed on to me is for example with my mother, as we disagree on many things. For example, she was doing bad because of things that were happening to my younger brother and she passed that feeling on to me. Because I notice that she places a lot of importance on thing that happen to him, and then they affect me and she doesn't see them as important".

Positive emotions:

"A positive energy, it happened with a friend I was speaking to and it came out that I was helping my neighbor with shopping, and she said she wanted to help him too. And she brought shopping for him. I was very happy with that gesture, especially knowing that it's useful for him (i.): [the neighbor]."

Personal "Lovely reflection, it touched me and made my cry. Only now can I distress listen..."

Modules $1 \quad$ "The issue of emotions I put into practice several years ago."

and 2 "With my children day by day we ask each other how we feel that day, and no matter how each of us feel we talk about it. Later I'll look at how to put into practice the rest even if it's tough to begin with."

"I learned to be very clear about my emotions and to better demonstrate the way I am."

When participants were asked to fill a satisfaction survey, they wrote phrases such as (quotes maintain the original expressions):

"I learned that little things can change my day-to-day life and that of others. That you don't need much to feel and be happy"

"I learned that you need to value the person by your side more and they have to value me more, to help. Also, the world needs more good people. I enjoy every moment with my children who are my driving force in life. And thank God I met many great people, and I thank God and life for putting good people in my path"

"The program deals with empathy, how to identify it, how to control it, how to share it, or think about things that I didn't think about before or didn't take into account. This also 
made me set foot in a different reality than the one I was in. Then I decided to understand and help people with little or a lot of empathy"

According to analysis of the coordinators' feedback and the final survey, all participants were grateful for the learning opportunity.

The results varied according to the relationship that the coordinators had with their groups and the project team. The closer the coordinators were to the beneficiaries and the stronger their conviction about the training program, the greater the commitment and attainment of the corresponding participants. The CSO coordinators were not only information mediators; they also played the role of "counselors" and confidants to the participants.

In the case of the group of beneficiaries who did not complete the final survey, the coordinators were not fully on board with the program on the grounds that it did not include content related to religion. The project team added two interventions that referred to the spiritual dimension of the individual. Analysis of the documents showed that this group made some small changes during the campaign, such as issuing invitations to religious activities and introducing phrases from spiritual leaders. For this reason, this group of beneficiaries was excluded from the quantitative analysis of the impact.

Consequently, although it can be observed that the implemented digitalization strategy increased the skills of the $\mathrm{CSO}(\mathrm{H} 3)$ and facilitated the implementation of its programs, its scope las limited by the previous experiences of the coordinators in empowering women and training.

To complete the impact analysis $(\mathrm{H} 2)$, the project, based on the mixed design of the intervention, applied a quasi-experimental design without a control group.

To evaluate the empathic disposition of women before and after the intervention, a reduced twelve-item version of the Argentine adaptation of the Interpersonal Reactivity Index (IRI) (Richaud, 2008). The items were selected for their relevance to the key dimensions, or factors, of empathy:

Empathic concern: Analyses feelings of compassion towards others.

Perspective-taking: The ability to understand the other person's point of view.

Distress or personal discomfort: Feelings of anxiety caused by the experiences of others.

Fantasy or imaginative ability.

At the start and the end of the program, the beneficiaries completed an online survey via the QuestionPro platform.

The scale presented a high level of internal consistency (Cronbach's Alpha $=.704$ ). The twelve variables on the IRI scale were used to form a simple indicator of "Level of Empathy" which proved to be greater at the end of the intervention $\left(M_{\text {pre-test }}=3.19, M_{\text {post- }}\right.$ test $=3.42$ ). 
To analyze the significance of the campaign's impact on the specific dimensions of empathy, Student's t-test was used for independent samples. In turn, Levene's test was used to determine the homogeneity of variance.

Table 3. Quantitative impact analysis. Source: Compiled by authors. Independent sample t-tests

\begin{tabular}{|c|c|c|c|c|c|c|c|c|c|}
\hline & \multicolumn{2}{|c|}{ Levene's test } & \multicolumn{7}{|c|}{ T-test for equality of means } \\
\hline & \multirow[b]{2}{*}{$\mathrm{F}$} & \multirow[b]{2}{*}{ Sig. } & \multirow[b]{2}{*}{$\mathrm{t}$} & \multirow[b]{2}{*}{$\mathrm{gl}$} & \multirow{2}{*}{$\begin{array}{c}\text { Sig. } \\
\text { (bilateral) }\end{array}$} & \multirow{2}{*}{$\begin{array}{l}\text { Difference in } \\
\text { means }\end{array}$} & \multirow{2}{*}{$\begin{array}{l}\text { Std. error of } \\
\text { the } \\
\text { difference }\end{array}$} & \multicolumn{2}{|c|}{$95 \%$ confidence interval } \\
\hline & & & & & & & & Lower & Upper \\
\hline $\begin{array}{l}\text { EMPATHIC } \\
\text { CONCERN }\end{array}$ & 64.173 & .000 & -3.535 & 44 & .001 & -1.34783 & .38129 & -2.11628 & -.57938 \\
\hline $\begin{array}{l}\text { PERSONAL } \\
\text { DISTRESS }\end{array}$ & 5.927 & .019 & -2.354 & 44 & .023 & -1.00000 & .42479 & -1.85610 & -.14390 \\
\hline
\end{tabular}

ANOVA descriptives

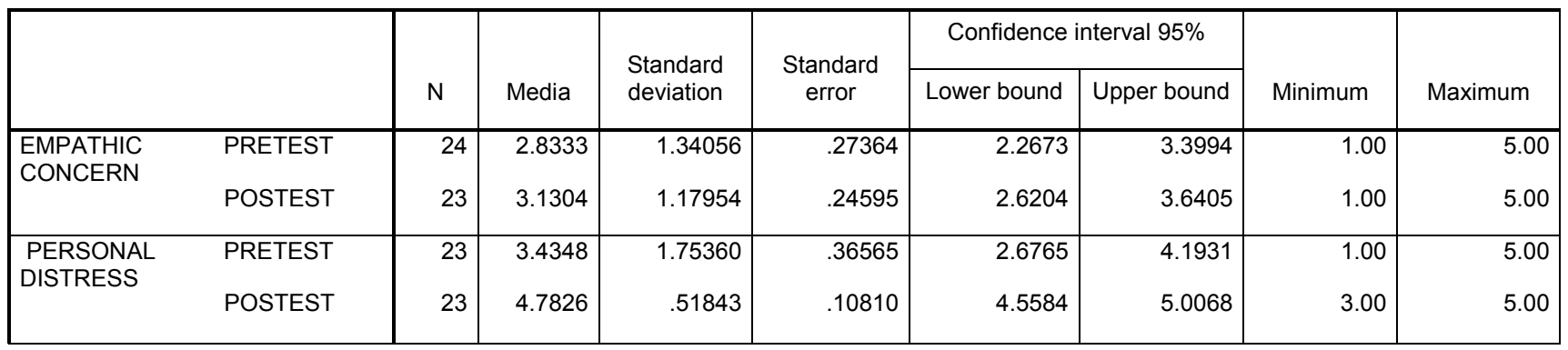

Table 3 shows the impact of the program was statistically significant (significance is lower than .05) in increasing empathic concern and self-control. The level of significance of the test allows the rejection of the null hypothesis, and acceptance of the alternative hypothesis, which is the hypothesis that the samples are different.

\section{Conclusions}

The investigation of the processes and impact of the implemented social marketing strategy show the positive effect of digitalization of training programs on the empathy of women in situations of social exclusion.

The design and use of a protocol based on a theoretical reference model not only allowed the participation and training of personnel of an international CSO, but also allowed the identification of a marketing mix and, more specifically, a service design based on microlearning that proved to be effective in empowering the beneficiary women through a social network $(\mathrm{H} 1)$.

The EduQualitas SM protocol favored the participant's digital social participation and, at the same time, improved their empathic abilities $(\mathrm{H} 2)$ through an accessible and wellknown platform, and a learning process that has positive effects in the medium term. 
The project enabled ANSPAC, unlike many CSOs operating in the Buenos Aires conurbation in the sphere of training for women, to continue assisting beneficiaries through service digitalization processes $(\mathrm{H} 3)$.

Consequently, social marketing based on evidence and a theoretical model can stimulate the digital transformation of the CSOs and improve the quality of life of its beneficiaries when, in addition to developing an appropriate mix of product, place, pricing, and promotion, it, through a strategic protocol, is oriented toward social innovation based in the continuous participation of its beneficiaries and actors.

Social marketing can serve as tool for change management, organizational transformation, and enhancing quality of life. As well as situations of social exclusion such as those encountered in the Buenos Aires conurbation.

\section{References}

Banco Interamericano de Desarrollo. (2017). Robotlución. Planeta. https://www.planetadelibros.com.ar/libro-robotlucion/257414

Baron, J. N. (2013). Empathy wages?: Gratitude and gift exchange in employment relationships. Research in Organizational Behavior, 33, 113-134. https://doi.org/10.1016/j.riob.2013.10.006

Bartholomew, L. K., Markham, C. M., Ruiter, R. A. C., Fernández, M. E., Kok, G., \& Parcel, G. S. (2016). Planning Health Promotion Programs: An Intervention Mapping Approach. John Wiley \& Sons.

Choi, J. (2006). A Motivational Theory of Charismatic Leadership: Envisioning, Empathy, and Empowerment. Journal of Leadership \& Organizational Studies, 13(1), 24-43. https://doi.org/10.1177/10717919070130010501

Deane Drummond, C. (2017). Empathy and the Evolution of Compassion: From Deep History to Infused Virtue. Zygon ${ }^{\circledR}, \quad 52(1), \quad 258-278$. https://doi.org/10.1111/zygo.12317

DeWall, C. N., \& Baumeister, R. F. (2006). Alone but feeling no pain: Effects of social exclusion on physical pain tolerance and pain threshold, affective forecasting, and interpersonal empathy. Journal of Personality and Social Psychology, 91(1), 1-15. https://doi.org/10.1037/0022-3514.91.1.1

Dutta, S., \& Bilbao-Osorio, B. (2012). The Global Information Technology Report 2012-Living in a Hyperconnected World. INSEAD - World Economic Forum. https://core.ac.uk/download/pdf/30679485.pdf\#page=147

Hall, N., Schmitz, H. P., \& Dedmon, J. M. (2020). Transnational Advocacy and NGOs in the Digital Era: New Forms of Networked Power. International Studies Quarterly, 64(1), 159-167. https://doi.org/10.1093/isq/sqz052

Hockenhull, J. C., Whittington, R., Leitner, M., Barr, W., McGuire, J., Cherry, M. G., Flentje, R., Quinn, B., Dundar, Y., \& Dickson, R. (2012). A Systematic Review of Prevention and Intervention Strategies for Populations at High Risk of 
Gustavo-Rivera, R. and Nogaró, J. (2020) Application of a Dialogic Social Marketing Model Based on Microlearning for the Development of Empathy Among Women at Risk of Exclusion, Vol.12(2): 52-69

Engaging in Violent Behaviour: Update 2002-8. Appendix 6. Protocol. Health Technology Assessment, 16(3). https://www.ncbi.nlm.nih.gov/books/NBK97417/

Jensen, D. C., Pedersen, L. B., \& Pedersen, L. B. (2017). The Impact of Empathy-Explaining Diversity in Street-Level Decision-Making. Journal of Public Administration Research and Theory, 27(3), 433-449. https://doi.org/10.1093/jopart/muw070

Jolliffe, D., \& Farrington, D. P. (2004). Empathy and offending: A systematic review and meta-analysis. Aggression and Violent Behavior, 9(5), 441-476. https://doi.org/10.1016/j.avb.2003.03.001

Kessler, G. (2015). Historia De La Provincia De Buenos Aires. Tomo 6. EDHASA. https://www.cuspide.com/9789876283601/6++Historia+De+La+Provincia+De+B uenos+Aires

Lane, R. E. (2001). Self-Reliance and Empathy: The Enemies of Poverty: And of the Poor. Political Psychology, 22(3), 473-492. JSTOR.

Marcus, R. F., \& Swett, B. (2003). Violence in close relationships: The role of emotion. Aggression and Violent Behavior, 8(3), 313-327. https://doi.org/10.1016/S1359-1789(01)00070-2

McLaren, K. (2013). The Art of Empathy: A Complete Guide to Life's Most Essential Skill (Edición: 10/16/13). Sounds True.

Observatorio de la Deuda Social UCA. (2020a, junio 24). Impacto Social de las Medidas de Aislamiento Obligatorio por COVID-19 en el AMBA. http://uca.edu.ar/es/noticias/serie-estudios-impacto-social-de-las-medidas-deaislamiento-obligatorio-por-covid19

Observatorio de la Deuda Social UCA. (2020b, septiembre 21). Según la UCA, la pobreza alcanza a 18 millones de personas | Política y Sociedad | Radio Universidad. Radio UNR. https://radio.unr.edu.ar/nota/6729/segun-la-uca-lapobreza-alcanza-a-18-millones-de-personas

OC UNGS. (2020). Contenido COVID-19. Observatorio del Conurbano Bonaerense. http://observatorioconurbano.ungs.edu.ar/?page_id=13507

OECD. (2019). Perfilando la transformación digital en América Latina. https://www.oecd-ilibrary.org/content/publication/4817d61b-es

Plataforma de ONG de Acción Social. (2019). El Tercer Sector de Acción Social en España 2019. NUEVOS HORIZONTES PARA UN NUEVO CONTEXTO SOCIOPOLÍTICO.

https://www.plataformaong.org/ARCHIVO/documentos/biblioteca/1583424466_i nforme-poas-completo.pdf

Prochaska, J. O., \& DiClemente, C. C. (1982). Transtheoretical therapy: Toward a more integrative model of change. Psychotherapy: Theory, Research \& Practice, 19(3), 276-288. https://doi.org/10.1037/h0088437

Richaud, M. C. (2008). Evaluación de la empatía en población infantil argentina. Revista de investigación en psicología, 11(1), 101-115. 
Rivera, R. (2011, mayo 11). Estrategias de alfabetización mediática. $1^{\circ}$ Congreso Comunicación y Educación. Safe Social Media - Integrando Teoría Y Evaluación De Impacto Para La Prevención De La Violencia En Medios Interactivos, Barcelona. http://communicationandeducation.wordpress.com/

Rivera, R. (2013). Adolescentes y Social Media: 4 Generaciones del Nuevo Milenio. Intermedia Social Innovation.

Rivera, R. (2019a). Preventing Youth Violence in El Salvador: A Relational Social Marketing Model. En M. M. Galan-Ladero \& H. M. Alves (Eds.), Case Studies on Social Marketing: A Global Perspective (pp. 195-204). Springer International Publishing. https://doi.org/10.1007/978-3-030-04843-3_17

Rivera, R. (2019b). Exploring Data Driven Youth Character Education Frameworks: A Systematic Literature Review on Learning Analytics Models and Participatory Design. Estudios sobre Educación, 37(0), 179-198. https://doi.org/10.15581/004.37.179-198

Rivera, R. G., Arrese, A., Sádaba, C., \& Casado, L. (2019). Incorporating Diversity in Marketing Education: A Framework for Including All People in the Teaching and Learning Process. Journal of Marketing Education, 0273475319878823. https://doi.org/10.1177/0273475319878823

Rivera, R. G., Castro Sanchez, M., \& Dimier de Vicente, M. D. (2019). Marketing social y violencia interpersonal. Un modelo aplicativo para el desarrollo de programas de prevención. QUADERNS DE POLÍTIQUES FAMILIARS, 05, 5065.

Rivera, R., Santos, D., Brändle, G., \& Cárdaba, M. Á. M. (2016). Design Effectiveness Analysis of a Media Literacy Intervention to Reduce Violent Video Games Consumption Among Adolescents The Relevance of Lifestyles Segmentation. Evaluation Review, 40(2), 142-161. https://doi.org/10.1177/0193841X16666196

Rodrigo, A., Ortale, S., Sanjurjo, A., Vojkovic, M., \& Piovani, J. (2006). Creencias y prácticas de crianza en familias pobres del conurbano bonaerense. Arch. argent. pediatr, 203-209.

Rodríguez Espínola, S., \& Salvia, A. (2019). Malestar subjetivo (2010-2018). Asimetrías sociales en los recursos emocionales, afectivos y cognitivos. (Observatorio de la Deuda Social Argentina. Barómetro de la Deuda Social Argentina. Documento de trabajo.). Universidad Católica Argentina. https://repositorio.uca.edu.ar/bitstream/123456789/8300/1/malestar-subjetivoasimetrias-sociales.pdf

Rogers, D. (2016). The Digital Transformation Playbook: Rethink Your Business for the Digital Age. Columbia Business School Publishing.

Rosa, H. (2013). Social Acceleration: A New Theory of Modernity. Columbia University Press.

Salinas, J., \& Marín, V. I. (2015). Pasado, presente y futuro del microlearning como estrategia para el desarrollo profesional. Campus Virtuales, 3(2), 46-61. 
Segal, E. A. (2007). Social Empathy: A New Paradigm to Address Poverty. Journal of Poverty, 11(3), 65-81. https://doi.org/10.1300/J134v11n03_06

Segal, E. A. (2018). Social Empathy: The Art of Understanding Others (p. 256 Pages). Columbia University Press.

Sze, J. A., Gyurak, A., Goodkind, M. S., \& Levenson, R. W. (2012). Greater emotional empathy and prosocial behavior in late life. Emotion, 12(5), 1129-1140. https://doi.org/10.1037/a0025011

Tonon, G. (Ed.). (2016). Indicators of Quality of Life in Latin America. Springer International Publishing. https://www.springer.com/gp/book/9783319288406

Tonon, G. (2017). Quality of Life in Communities of Latin Countries. Springer.

Trabaldo, S., Mendizábal, V., \& González Rozada, M. (2017). Microlearning: Experiencias reales de aprendizaje personalizado, rápido y ubicuo. IV Jornadas de TIC e Innovación en el Aula (La Plata, 2017). http://sedici.unlp.edu.ar/handle/10915/65550

UNESCO. (2016, diciembre 15). NGOs and the Digital Revolution. UNESCO. https://en.unesco.org/news/ngos-and-digital-revolution-0 